A trifugal ultrafitration, protein (DBP) in 24 normal subjects, 17 pregnant subjects, and 25 alcoholic subjects with liver disease. Our objective was to determine whether the increase in total $1,25(\mathrm{OH})_{2} \mathrm{D}$ levels in pregnant women and the reduction in total $1,25(\mathrm{OH})_{2} \mathrm{D}$ levels in subjects with liver disease reflected a true difference in free $1,25(\mathrm{OH})_{2} \mathrm{D}$ levels or whether such differences were due solely to the variations in DBP levels (and thus, the amount of $1,25[\mathrm{OH}]_{2} \mathrm{D}$ bound) in these groups. In subjects with liver disease the mean total $1,25(\mathrm{OH})_{2} \mathrm{D}$ concentration $(22.6 \pm 12.5$ $\mathrm{pg} / \mathrm{ml})$ and the mean DBP concentration $(188 \pm 105 \mu \mathrm{g} /$ dl) were nearly half the normal values $(41.5 \pm 11.5 \mathrm{pg} /$ $\mathrm{ml}$ and $404 \pm 124 \mu \mathrm{g} / \mathrm{dl}$, respectively, $P<0.001$ ), whereas the mean free $1,25(\mathrm{OH})_{2} \mathrm{D}$ level was similar to normal values $(209 \pm 91 \mathrm{fg} / \mathrm{ml}$ and $174 \pm 46 \mathrm{fg} / \mathrm{ml}$, respectively). In contrast, in pregnant subjects the mean total $1,25(\mathrm{OH})_{2} \mathrm{D}$ level $(82 \pm 21 \mathrm{pg} / \mathrm{ml})$ and mean DBP level $(576 \pm 128 \mu \mathrm{g} / \mathrm{dl})$ were significantly higher than normal $(P<0.001)$. Although the mean percent free 1,25 $(\mathrm{OH})_{2} \mathrm{D}$ level in pregnant subjects was below normal $(0.359 \pm 0.07 \%$ vs. $0.424 \pm 0.07 \%, P<0.001)$, the mean free $1,25(\mathrm{OH})_{2} \mathrm{D}$ level was $69 \%$ higher than normal $(294 \pm 98 \mathrm{fg} / \mathrm{ml}$ vs. $174 \pm 46 \mathrm{fg} / \mathrm{ml}, P<0.001)$. When data from all three groups were combined, there was a linear correlation between total $1,25(\mathrm{OH})_{2} \mathrm{D}$ and $\mathrm{DBP}$ levels but not between DBP and percent free $1,25(\mathrm{OH})_{2} \mathrm{D}$

Address correspondence to Dr. Bikle, VA Medical Center (111N), 4150 Clement St., San Francisco, CA 94121.

Received for publication 28 December 1983 and in revised form 24 July 1984.

The Journal of Clinical Investigation, Inc.

Volume 74, December 1984, 1966-1971

\section{Free 1,25-Dihydroxyvitamin D Levels in Serum from Normal Subjects, Pregnant Subjects, and Subjects with Liver Disease}

Daniel D. Bikle, Elaine Gee, Bernard Halloran, and John G. Haddad

University of California and Veterans Administration Medical Center, San Francisco, California 94121; University of Pennsylvania School of Medicine, Philadelphia,

Pennsylvania 19104

levels; the increased DBP levels in the pregnant subjects were associated with less of an effect on percent free $1,25(\mathrm{OH})_{2} \mathrm{D}$ than were the reduced DBP levels in the subjects with liver disease.

Our data suggest that $(a)$ free $1,25(\mathrm{OH})_{2} \mathrm{D}$ levels appear to be well maintained even in subjects with liver disease and reduced DBP levels, $(b)$ free $1,25(\mathrm{OH})_{2} \mathrm{D}$ levels are increased during pregnancy despite the increase in DBP levels, and $(c)$ free $1,25(\mathrm{OH})_{2} \mathrm{D}$ levels cannot be inferred accurately from measurements of total $1,25(\mathrm{OH})_{2} \mathrm{D}$ and DBP levels alone in subjects with various physiologic and pathophysiologic conditions.

\section{Introduction}

Vitamin D and its metabolites circulate in blood almost entirely bound to serum proteins (1). The best studied of these proteins is vitamin D-binding protein (DBP), ${ }^{1}$ an alpha globulin with a molecular weight of $\sim 58,000$ (2), although lipoproteins and albumin are also known to bind the vitamin $D$ metabolites (3). The high affinity of DBP for the vitamin D metabolites, coupled with the large excess of DBP in blood compared with the vitamin $\mathrm{D}$ metabolites, has made it difficult to measure the free or unbound fraction of the circulating metabolites. Instead, levels of the free metabolites have been estimated from measurements of DBP and total metabolite concentrations, using previous determinations of the affinity constant of purified DBP or dilute serum for the vitamin D metabolite of interest (4). However, estimates of the affinity constant of human DBP for 25-hydroxyvitamin D (25OHD) vary from $1.6 \times 10^{7} \mathrm{M}^{-1}$ to $2 \times 10^{10} \mathrm{M}^{-1}(2,5-7)$, creating considerable uncertainty in the estimation of free metabolite by this approach. Fewer estimates of the affinity of DBP for 1,25dihydroxyvitamin $\mathrm{D}\left(1,25[\mathrm{OH}]_{2} \mathrm{D}\right)$ have been reported, but

1. Abbreviations used in this paper: DBP, vitamin D-binding protein; HPLC, high-pressure liquid chromatography; 25OHD, 25-hydroxyvitamin $\mathrm{D} ; 1,25(\mathrm{OH})_{2} \mathrm{D}, 1,25$-dihydroxyvitamin $\mathrm{D}$. 
the affinity appears to be at least one order of magnitude less than that for 25OHD $(2,4)$. The exact relationship between these affinity constant determinations, which generally are made using dilute serum at $4^{\circ} \mathrm{C}$, and the actual free levels of $1,25(\mathrm{OH})_{2} \mathrm{D}$ in undiluted blood at $37^{\circ} \mathrm{C}$ is unknown.

Determination of free $1,25(\mathrm{OH})_{2} \mathrm{D}$ levels in human blood is important because it is still unclear whether the free or the total concentration of this hormone is the physiologically important concentration. Total $1,25(\mathrm{OH})_{2} \mathrm{D}$ levels are increased during pregnancy $(4,8-11)$, as are DBP levels $(4,8,12-14)$. Pregnant women do not develop hypercalcemia, as might be expected in persons with elevated $1,25(\mathrm{OH})_{2} \mathrm{D}$ levels, although increased intestinal calcium absorption has been observed (15). Perhaps the increase in total $1,25(\mathrm{OH})_{2} \mathrm{D}$ reflects an increase in the amount of $1,25(\mathrm{OH})_{2} \mathrm{D}$ bound to DBP (analogous to the rise in thyroid hormone and cortisol during pregnancy) and not an increase in the free concentration. Patients with liver disease $(16-18)$ and the nephrotic syndrome $(19,20)$ have DBP levels that are lower than normal. Low $1,25(\mathrm{OH})_{2} \mathrm{D}$ concentrations have been reported in these conditions by some investigators $(21,22)$ but not by others $(23,24)$. If levels are indeed lower, this circumstance may be caused by a reduction in the amount of $1,25(\mathrm{OH})_{2} \mathrm{D}$ bound to DBP, although abnormalities in hepatic or renal metabolism of vitamin $D$ in such patients may be partially responsible. The finding of osteomalacia in some patients with liver disease $(22,25)$ or the nephrotic syndrome (26) is difficult to reconcile with the concept that the $1,25(\mathrm{OH})_{2} \mathrm{D}$ bound to $\mathrm{DBP}$ is physiologically inactive, unless the free $1,25(\mathrm{OH})_{2} \mathrm{D}$ levels are also reduced in these conditions. Thus, in all these patients, knowledge of free $1,25(\mathrm{OH})_{2} \mathrm{D}$ levels would be helpful in understanding the pathophysiology involved.

In an attempt to find a technique that could measure free $1,25(\mathrm{OH})_{2} \mathrm{D}$ levels directly, accurately, and rapidly, we compared measurements of free $1,25(\mathrm{OH})_{2} \mathrm{D}$ levels made by centrifugal ultrafiltration and by equilibrium dialysis. We then used centrifugal ultrafiltration to measure free $1,25(\mathrm{OH})_{2} \mathrm{D}$ levels in subjects with low (chronic liver disease), normal, and high (pregnancy) DBP levels to determine the relationship between free $1,25(\mathrm{OH})_{2} \mathrm{D}$ and $\mathrm{DBP}$ levels.

\section{Methods}

Subjects. Blood was obtained from 24 normal volunteers (eight men and 16 women, aged 24-50 yr), 17 pregnant subjects, 15 of whom were in their third trimester of pregnancy, and 25 alcoholic subjects ( 7 women and 18 men, aged 22 to 70 ) with clinical or histologic evidence of liver disease. The normal volunteers and the subjects with liver disease were taking no drugs known to influence levels of vitamin D metabolites or DBP, except for three normal subjects who were taking oral contraceptives. The pregnant subjects were ingesting each day a prenatal vitamin supplement containing $400 \mathrm{IU}$ vitamin $D_{2}$. No subject had a disorder in calcium metabolism that was clinically apparent. The serum was stored at $-20^{\circ} \mathrm{C}$ until assayed.

Analyses. The centrifugal ultrafiltration technique of Hammond et al. (27) was employed. The tritiated $\left({ }^{3} \mathrm{H}\right) 1,25(\mathrm{OH})_{2} \mathrm{D}$ used as tracer was purified by high-pressure liquid chromatography (HPLC) just before each assay using a Zorbax Sil column (E. I. DuPont de Nemours \& Co., Inc., Wilmington, DE) and a 9:1 concentration of hexane to isopropanol. The $\left[{ }^{3} \mathrm{H}\right] 1,25(\mathrm{OH})_{2} \mathrm{D}$ was biosynthesized from 25 hydroxy[26(27)-methyl- ${ }^{3} \mathrm{H}$ ]cholecalciferol $(153 \mathrm{Ci} / \mathrm{mmol}$; Amersham Corp., Arlington Heights, IL) by the method described below. 0.1-0.2 $\mu \mathrm{Ci}$ of $\left[{ }^{3} \mathrm{H}\right] 1,25(\mathrm{OH})_{2} \mathrm{D}$ and $7,500 \mathrm{dpm}$ of $\left[{ }^{14} \mathrm{C}\right] \mathrm{glucose}$ (Amersham Corp.) were dried under $\mathrm{N}_{2} ; 0.45 \mathrm{ml}$ serum was added, and the mixture was incubated for $45 \mathrm{~min}$ at $37^{\circ} \mathrm{C}$ in a shaking water bath. Two 200- $\mu$ l aliquots were removed, and each was placed in the inner tube of an ultrafiltration vial, which was then centrifuged at $2,000 \mathrm{~g}$ for $90 \mathrm{~min}$ at $37^{\circ} \mathrm{C}$. At the end of centrifugation, $30 \mu \mathrm{l}$ of the contents of the inner tube (serum) and the contents of the outer vial (ultrafiltrate) were analyzed for $\left[{ }^{14} \mathrm{C}\right]$ and $\left[{ }^{3} \mathrm{H}\right]$ by dual-label liquid scintillation spectroscopy. The percent free $1,25(\mathrm{OH})_{2} \mathrm{D}=\left[{ }^{3} \mathrm{H}\right] \mathrm{u} /\left[{ }^{[4} \mathrm{C}\right] \mathrm{u} \times\left[{ }^{14} \mathrm{C}\right] \mathrm{s} /$ $\left[{ }^{3} \mathrm{H}\right] \mathrm{s} \times 100$, where $\mathrm{u}$ is ultrafiltrate and $\mathrm{s}$ is serum.

Equilibrium dialysis was performed in plexiglass dialysis units, with the chambers separated by the same type of dialysis membrane (molecular weight cutoff, 12,000; Arthur H. Thomas Co., Philadelphia, PA) used for centrifugal ultrafiltration (28). $0.2 \mu \mathrm{Ci}$ freshly purified $\left[{ }^{3} \mathrm{H}\right] 1,25(\mathrm{OH})_{2} \mathrm{D}$ was dried under $\mathrm{N}_{2}$, and then incubated with $1.6 \mathrm{ml}$ serum as before $\left(45 \mathrm{~min}, 37^{\circ} \mathrm{C}\right)$. After incubation, two 0.75 - $\mathrm{ml}$ aliquots of the serum were removed and each was placed in a sample well; 2.6 $\mathrm{ml}$ phosphate-buffered saline $(0.01 \mathrm{M}$ phosphate, $154 \mathrm{mM} \mathrm{NaCl}, \mathrm{pH}$ 7.4) was placed in the buffer well. The sample and buffer were kept in the wells at $37^{\circ} \mathrm{C}$ for $48 \mathrm{~h}$. At the end of this period aliquots of sample and buffer were analyzed for $\left[{ }^{3} \mathrm{H}\right]$ by liquid scintillation spectroscopy. Percent free $1,25(\mathrm{OH})_{2} \mathrm{D}=\left[{ }^{3} \mathrm{H}\right] \mathrm{b} /\left[{ }^{3} \mathrm{H}\right] \mathrm{s} \times 100$, where $\left[{ }^{3} \mathrm{H}\right] \mathrm{b}=\mathrm{dpm}$ $\left[{ }^{3} \mathrm{H}\right] / \mathrm{ml}$ of buffer and $\left[{ }^{3} \mathrm{H}\right] \mathrm{s}=\mathrm{dpm}\left[{ }^{3} \mathrm{H}\right] / \mathrm{ml}$ of sample. Binding of radiolabel to the walls of the chamber was assessed by rinsing the chambers with methanol after removing the sample and buffer.

Total 25OHD levels were determined by the method of Haddad and Chyu (29), using chemically synthesized $25 \mathrm{OHD}_{3}$ (gift from Dr. J. D. Babcock, Upjohn Co., Kalamazoo, MI) as standard. The total $1,25(\mathrm{OH})_{2} \mathrm{D}$ levels in serum were determined by the method of Eisman et al. (30) using chemically synthesized $1,25(\mathrm{OH})_{2} \mathrm{D}$ (gift from $\mathrm{M}$. $\mathrm{R}$. Uskokovic, Hoffmann-LaRoche, Inc., Nutley, NJ) as standard.

DBP levels were measured by rocket immunoelectrophoresis (31) using purified human DBP as standard and monospecific antisera prepared in rabbits.

Biosynthesis of $\left[{ }^{3} \mathrm{H}\right] 1,25(\mathrm{OH})_{2} \mathrm{D}$. Mitochondria were prepared by the method of Bikle et al. (32) from the kidneys of 6-wk-old chicks raised from hatching on a diet that contained $1 \% \mathrm{Ca}, 0.65 \% \mathrm{P}$, and was deficient in vitamin $D$. The final incubation mixture contained 5 mg mitochondrial protein per milliliter, $10 \mathrm{mM}$ sodium pyruvate, 4 $\mathrm{mM} \mathrm{MgSO}_{4}, 10^{-5} \mathrm{M}$ free calcium (buffered by $10 \mathrm{mM}$ EGTA), 10 $\mathrm{mM}$ sodium phosphate, $100 \mathrm{mM} \mathrm{KCl}, 90 \mathrm{mM}$ sucrose, and $10 \mathrm{mM}$ Tris- $\mathrm{HCl}, \mathrm{pH}$ 6.8. $\left[{ }^{3} \mathrm{H}\right] 25 \mathrm{OHD}$ was added in ethanol (final ethanol concentration was $1 \%$ ), and the mixture was incubated for $2 \mathrm{~h}$ under $1 \mathrm{~atm} \mathrm{O}_{2}$. The incubate was extracted, and the $1,25(\mathrm{OH})_{2} \mathrm{D}$ was purified by paper chromatography (SG-81 paper) and HPLC as previously described (33). The purified $\left[{ }^{3} \mathrm{H}\right] 1,25(\mathrm{OH})_{2} \mathrm{D}$ was stored under $\mathrm{N}_{2}$ in ethanol at $-80^{\circ} \mathrm{C}$ until used. Aliquots of the stock were repurified by HPLC just before use for the free $1,25(\mathrm{OH})_{2} \mathrm{D}$ determinations.

Statistical analyses. Student's $t$ test was used to determine the significance of differences between groups. Correlations between sets of data used linear regression unless otherwise indicated. All group data are expressed as mean \pm SD. 


\section{Results}

The duration of the incubation of $\left[{ }^{3} \mathrm{H}\right] 1,25(\mathrm{OH})_{2} \mathrm{D}$ with serum before centrifugal ultrafiltration indicated that essentially complete binding was achieved rapidly. The apparent percent free $1,25(\mathrm{OH})_{2} \mathrm{D}$ ultimately measured varied from $0.39 \pm 0.01$ to $0.34 \pm 0.02$ when the incubation time was extended from 5 to $60 \mathrm{~min}$. A 45-min incubation of radioligand and serum was chosen for all further assays. Increasing the ambient $\mathrm{CO}_{2}$ concentration from 0 to $10 \%$ during incubation and centrifugation had little effect on percent free $1,25(\mathrm{OH})_{2} \mathrm{D}(0.380 \pm 0.05$ and $0.376 \pm 0.008$, respectively). All subsequent experiments were performed at room air. The addition of increasing amounts of unlabeled $1,25(\mathrm{OH})_{2} \mathrm{D}$ from trace amounts $(1.5$ $\times 10^{-9} \mathrm{M}$ ) to $2.2 \times 10^{-6} \mathrm{M}$ had no significant effect on the apparent percent free $1,25(\mathrm{OH})_{2} \mathrm{D}(0.35 \pm 0.04$ to $0.33 \pm 0.01)$. This finding reflects the large excess of high-affinity binding sites for $1,25(\mathrm{OH})_{2} \mathrm{D}$ in serum. To determine that the radiolabel passing through the membrane during centrifugal ultrafiltration was intact $\left[{ }^{3} \mathrm{H}\right] 1,25(\mathrm{OH})_{2} \mathrm{D}$, we extracted the ultrafiltrate and subjected it to HPLC. $85 \%$ of the label in the extract was recovered in the $1,25(\mathrm{OH})_{2} \mathrm{D}$ peak. No other peaks were observed. The intra-assay coefficient of variation in the determination of percent free $1,25(\mathrm{OH})_{2} \mathrm{D}$ was $13 \%$ in 12 replications; the interassay coefficient of variation was $26 \%$ in eight consecutive assays performed over a 12 -mo period using two different preparations of $\left[{ }^{3} \mathrm{H}\right] 1,25(\mathrm{OH})_{2} \mathrm{D}$.

The free concentration of $1,25(\mathrm{OH})_{2} \mathrm{D}$ was determined in 10 normal subjects both by centrifugal ultrafiltration and by equilibrium dialysis for $48 \mathrm{~h}$. The total $1,25(\mathrm{OH})_{2} \mathrm{D}$ level in this group was $44 \pm 13 \mathrm{pg} / \mathrm{ml}$. The percent free $1,25(\mathrm{OH})_{2} \mathrm{D}$ level was $0.49 \pm 0.12$ by centrifugal ultrafiltration, and $0.55 \pm 0.15$ by equilibrium dialysis. These values are not significantly different. The free $1,25(\mathrm{OH})_{2} \mathrm{D}$ levels calculated from the total and percent free $1,25(\mathrm{OH})_{2} \mathrm{D}$ were $214 \pm 75 \mathrm{fg} / \mathrm{ml}$ by centrifugal ultrafiltration and $233 \pm 94 \mathrm{fg} / \mathrm{ml}$ by equilibrium dialysis.

Equilibrium dialysis, however, proved to be an unreliable method for the determination of free $1,25(\mathrm{OH})_{2} \mathrm{D}$ in our study. In some experiments (as in the one described above), apparent equilibrium was achieved within $48 \mathrm{~h}$ of dialysis; the free $1,25(\mathrm{OH})_{2} \mathrm{D}$ concentration did not change between 24 and $72 \mathrm{~h}$. In other experiments, apparent equilibrium was not achieved even after $96 \mathrm{~h}$. Two reasons for this became clear. First, $\sim 40 \%$ of the radiolabel passing from serum sample to buffer could be eluted from the walls of the dialysis chamber with methanol after the sample and buffer had been removed and the chambers rinsed with buffer. Second, the purity of the radiolabel recovered in the buffer (i.e., the percent of radiolabel recovered as $\left[{ }^{3} \mathrm{H}\right] 1,25(\mathrm{OH})_{2} \mathrm{D}$ following HPLC) fell from $100 \%$ at $0 \mathrm{~h}$ to $30 \%$ at $96 \mathrm{~h}$. For these reasons, we used centrifugal ultrafiltration for all subsequent determinations of free $1,25(\mathrm{OH})_{2} \mathrm{D}$.

Subjects in whom DBP levels were expected to be either low (liver disease) or high (pregnancy) were compared with normal subjects. Their levels for total $25 \mathrm{OHD}$ and $1,25(\mathrm{OH})_{2} \mathrm{D}$, percent free $1,25(\mathrm{OH})_{2} \mathrm{D}$, free $1,25(\mathrm{OH})_{2} \mathrm{D}$, and $\mathrm{DBP}$ are depicted in Table I. Subjects with liver disease had the lowest total $1,25(\mathrm{OH})_{2} \mathrm{D}(22.6 \pm 12.5 \mathrm{pg} / \mathrm{ml})$ and DBP $(188 \pm 105$ $\mu \mathrm{g} / \mathrm{dl})$ levels, and the highest percent free $1,25(\mathrm{OH})_{2} \mathrm{D}$ $(1.098 \pm 0.5 \%)$. Pregnant subjects had the highest total $1,25(\mathrm{OH})_{2} \mathrm{D}(82 \pm 21 \mathrm{pg} / \mathrm{ml})$ and DBP $(576 \pm 128 \mu \mathrm{g} / \mathrm{dl})$ levels and the lowest percent free $1,25(\mathrm{OH})_{2} \mathrm{D}(0.359 \pm 0.07 \%)$. The mean free $1,25(\mathrm{OH})_{2} \mathrm{D}$ levels did not differ significantly for subjects with liver disease and normal subjects (174 \pm 46 vs. $209 \pm 91 \mathrm{fg} / \mathrm{ml}$, respectively, $P>0.05)$. In contrast, in pregnant subjects the mean free $1,25(\mathrm{OH})_{2} \mathrm{D}$ level was significantly higher than that in normal subjects $(294 \pm 98 \mathrm{fg} / \mathrm{ml}$ vs. $174 \pm 46$ $\mathrm{fg} / \mathrm{ml}$, respectively). Normal men and women did not differ in their mean free $1,25(\mathrm{OH})_{2} \mathrm{D}$ levels (women, $177 \pm 53 \mathrm{fg} / \mathrm{ml}$; men, $168 \pm 33 \mathrm{fg} / \mathrm{ml})$. In the three normal women who were ingesting oral contraceptives, the mean free $1,25(\mathrm{OH})_{2} \mathrm{D}$ level $(235 \pm 47 \mathrm{fg} / \mathrm{ml})$ was between the values for normal $(174 \pm 46$ $\mathrm{fg} / \mathrm{ml})$ and pregnant subjects $(294 \pm 98 \mathrm{fg} / \mathrm{ml})$, even though these three women had a mean DBP level $(603 \pm 228 \mu \mathrm{g} / \mathrm{dl})$ comparable to that of the pregnant subjects $(576 \pm 128 \mu \mathrm{g} / \mathrm{dl})$.

There was a linear correlation between total serum $1,25(\mathrm{OH})_{2} \mathrm{D}$ levels and DBP levels when data from all three groups of subjects were combined (Fig. $1, r=0.757, P$ $<0.001)$. There was no correlation when data from the normal or pregnant subjects were analyzed separately.

The correlation between DBP and percent free $1,25(\mathrm{OH})_{2} \mathrm{D}$ was not linear when data from all three groups were combined (Fig. 2), but the percent free $1,25(\mathrm{OH})_{2} \mathrm{D}$ could be expressed as a power function of DBP (Fig. 3), with a significant correlation coefficient $(r=-0.815, P<0.001)$. When data from the subjects with liver disease and pregnant subjects were analyzed separately, significant linear correlations could be found between percent free $1,25(\mathrm{OH})_{2} \mathrm{D}$ and DBP levels $(r$ $=-0.447, P<0.05$ and $r=-0.615, P<0.01$, for subjects

Table I. Levels of Total 1,25(OH $)_{2}$ D,

Free $1,25(\mathrm{OH})_{2} D$, and $D B P$ in Normal Subjects, Subjects with Liver Disease, and Pregnant Subjects

\begin{tabular}{|c|c|c|c|}
\hline & $\begin{array}{l}\text { Normal } \\
\text { subjects* } \\
(n=24)\end{array}$ & $\begin{array}{l}\text { Subjects with } \\
\text { liver disease } \\
(n=25)\end{array}$ & $\begin{array}{l}\text { Pregnant } \\
\text { subjects } \\
(n=17)\end{array}$ \\
\hline Total 25OHD & $19.2 \pm 6.6$ & $9.7 \pm 4.5 \ddagger$ & $27.8 \pm 8.8 \ddagger$ \\
\hline Total $1,25(\mathrm{OH})_{2} \mathrm{D}$ & $41.5 \pm 11.5$ & $22.6 \pm 12.5 \ddagger$ & $82 \pm 21 \ddagger$ \\
\hline \multicolumn{4}{|l|}{ Percent free } \\
\hline $1,25(\mathrm{OH})_{2} \mathrm{D}$ & $0.424 \pm 0.07$ & $1.098 \pm 0.50 \ddagger$ & $0.359 \pm 0.07 \ddagger$ \\
\hline Free $1,25(\mathrm{OH})_{2} \mathrm{D}$ & $174 \pm 46$ & $209 \pm 91$ & $294 \pm 98 \ddagger$ \\
\hline DBP§ & $404 \pm 124$ & $188 \pm 105 \ddagger$ & $576 \pm 128 \ddagger$ \\
\hline
\end{tabular}

* Data include three women taking oral contraceptives.

$\neq P<0.001$ compared with normal values.

$\S$ DBP was measured in only 18 normal subjects but in all 25 subjects with liver disease and all 17 pregnant subjects. 


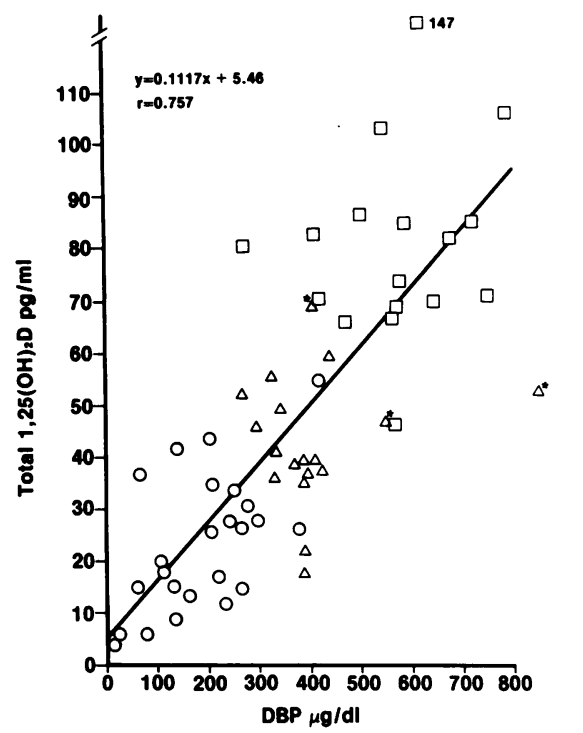

Figure 1. Correlation between total $1,25(\mathrm{OH})_{2} \mathrm{D}$ and DBP levels in the serum of 18 normal subjects $(\Delta), 25$ subjects with liver disease $(0)$, and 17 pregnant subjects $(\square)$. * Normal subjects ingesting oral contraceptives.

with liver disease and pregnant subjects, respectively), but the slopes of the regression lines were quite different. Normal subjects showed no significant correlation between these measurements.

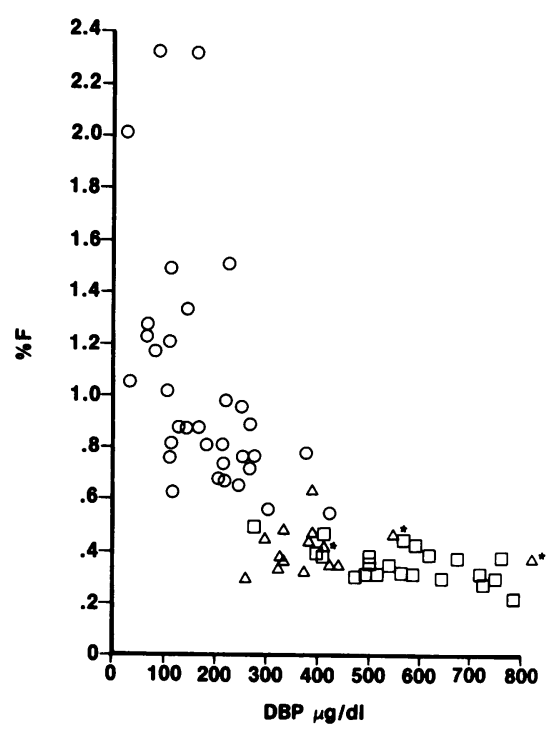

Figure 2. Correlation between percent free $1,25(\mathrm{OH})_{2} \mathrm{D}(\% \mathrm{~F})$ and DBP levels in 18 normal sujects $(\Delta), 34$ subjects with liver disease $(0)$, and 17 pregnant subjects $(\square)$. Nine additional subjects with liver disease in whom percent free but not total $1,25(\mathrm{OH})_{2} \mathrm{D}$ was determined are included. * Normal subjects ingesting oral contraceptives.

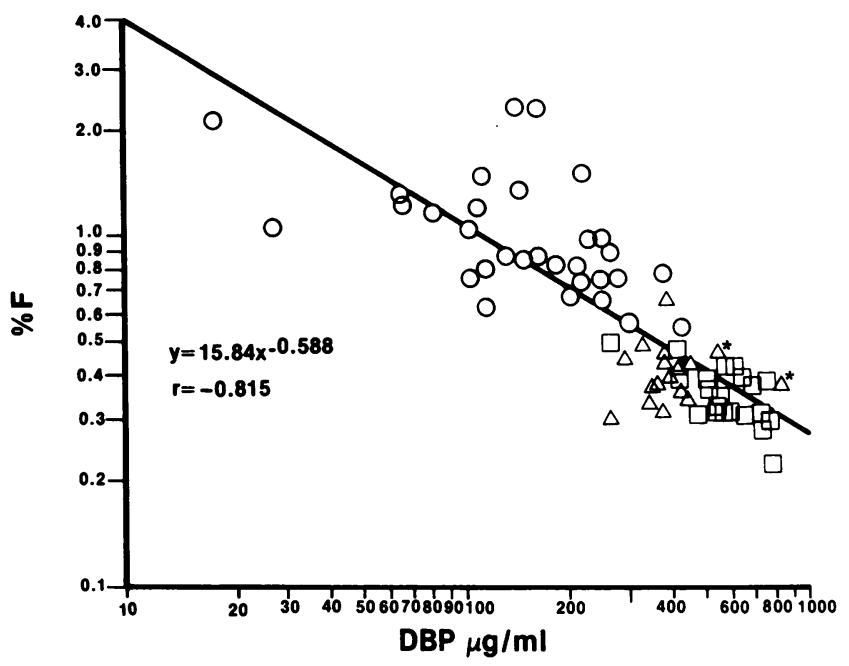

Figure 3. A $\log / \log$ plot of the correlation between percent free $1,25(\mathrm{OH})_{2} \mathrm{D}(\% \mathrm{~F})$ and DBP levels in 18 normal subjects $(\Delta), 34$ subjects with liver disease (O), and 17 pregnant subjects ( $\square$ ). Data from fig. 2 were used. * Normal subjects ingesting oral contraceptives.

No correlation between free $1,25(\mathrm{OH})_{2} \mathrm{D}$ and DBP levels was observed when data from all three groups were combined (Fig. 4).

\section{Discussion}

The biologically active metabolite of vitamin $\mathrm{D}, 1,25(\mathrm{OH})_{2} \mathrm{D}$, circulates in blood tightly bound to serum proteins. Only a

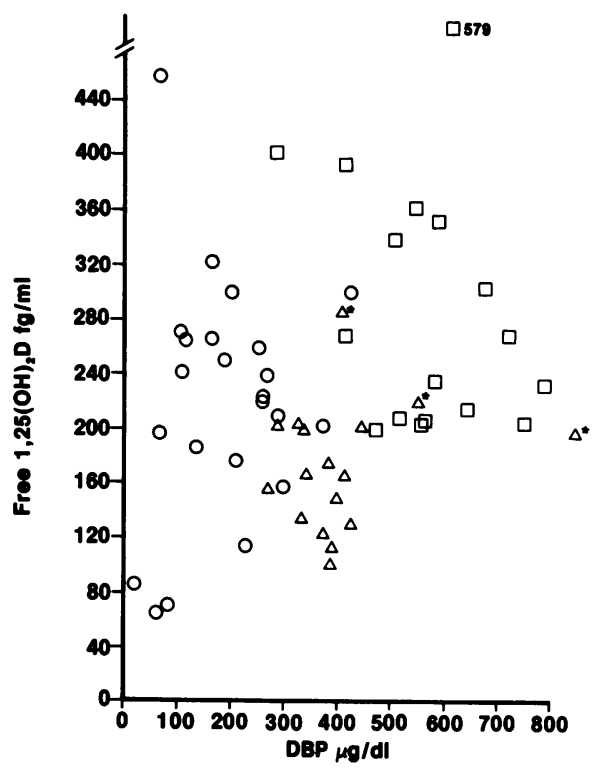

Figure 4. Comparison of free $1,25(\mathrm{OH})_{2} \mathrm{D}$ and DBP levels in 18 normal subjects $(\Delta), 25$ subjects with liver disease $(0)$, and 17 pregnant subjects $(\square) . *$ Normal subjects ingesting oral contraceptives. 
small fraction remains free, yet this free fraction may be physiologically important in regulating the function of target tissues. The free fraction has been difficult to measure because the binding affinity and capacity of serum for $1,25(\mathrm{OH})_{2} \mathrm{D}$ are so high.

We employed centrifugal ultrafiltration to separate free and bound $1,25(\mathrm{OH})_{2} \mathrm{D}$. This technique offers advantages over other methods such as equilibrium dialysis in that it is relatively rapid (90 $\mathrm{min}$ ) and uses small sample volumes of undiluted serum $(200 \mu \mathrm{l})$. Both centrifugal ultrafiltration and equilibrium dialysis require pure radiolabeled $1,25(\mathrm{OH})_{2} \mathrm{D}$ since the distribution of the radiolabel across the membrane is what actually is measured. We purified radiolabel just before each assay. $85 \%$ of the radiolabel in the ultrafiltrate was recovered as $1,25(\mathrm{OH})_{2} \mathrm{D}$, and there were no other detectable peaks when the ultrafiltrate was resubjected to HPLC. Our experience indicates that much of the remaining $15 \%$ could be because of loss of sample during extraction and chromatography; we therefore believe that the radiolabel in the ultrafiltrate is almost entirely $1,25(\mathrm{OH})_{2} \mathrm{D}$. In contrast, the prolonged incubations required for equilibrium dialysis resulted in substantial deterioration of the radiolabel.

Because the free fraction of $1,25(\mathrm{OH})_{2} \mathrm{D}$ is so small and the ultrafiltrate obtained during centrifugation so limited (30 $\mu \mathrm{l})$, substantial amounts of radioactivity $(0.1$ to $0.2 \mu \mathrm{Ci})$ must be added to each sample to obtain adequate amounts of radioactivity in the ultrafiltrate. This circumstance poses two potential problems. First, the amount of $1,25(\mathrm{OH})_{2} \mathrm{D}$ added as radiolabel $(2-4 \mathrm{pmol} / \mathrm{ml})$ exceeds the total amount of endogenous $1,25(\mathrm{OH})_{2} \mathrm{D}$ in the serum sample. However, the binding capacity and affinity of serum for $1,25(\mathrm{OH})_{2} \mathrm{D}$ are so high that, until concentrations of $1,25(\mathrm{OH})_{2} \mathrm{D}$ greater than 2 $\times 10^{-6} \mathrm{M}$ are reached, no apparent displacement of bound $1,25(\mathrm{OH})_{2} \mathrm{D}$ can be observed. The second potential problem is expense. We reduce this problem by biosynthesizing $\left[{ }^{3} \mathrm{H}\right] 1,25(\mathrm{OH})_{2} \mathrm{D}$ from the much less expensive $\left[{ }^{3} \mathrm{H}\right] 25 \mathrm{OHD}$ ourselves. Our method results in a high conversion rate (>90\%) of $\left[{ }^{3} \mathrm{H}\right] 25 \mathrm{OHD}$ to $\left[{ }^{3} \mathrm{H}\right] 1,25(\mathrm{OH})_{2} \mathrm{D}$.

Although Silver and Fainaru (3) have presented evidence that lipoproteins and albumin bind a substantial percentage of vitamin $\mathrm{D}$ and $1,25(\mathrm{OH})_{2} \mathrm{D}$ in blood, the major binding protein currently thought to be responsible for the transport of vitamin D and its metabolites in blood is DBP. Changes in DBP concentrations could alter total $1,25(\mathrm{OH})_{2} \mathrm{D}$ levels without affecting free $1,25(\mathrm{OH})_{2} \mathrm{D}$ levels. Pregnancy and estrogen therapy raise $\mathrm{DBP}$ and total $1,25(\mathrm{OH})_{2} \mathrm{D}$ levels $(4,8-14)$. Liver disease can lower DBP levels (16-18) and, according to some reports (22), including our own data, can lower total $1,25(\mathrm{OH})_{2} \mathrm{D}$ levels. To determine whether free $1,25(\mathrm{OH})_{2} \mathrm{D}$ levels were also affected by these conditions, we measured total and free $1,25(\mathrm{OH})_{2} \mathrm{D}$ and DBP levels in such patients. Alcoholic subjects with liver disease had substantially lower DBP and total $1,25(\mathrm{OH})_{2} \mathrm{D}$ levels than did normal subjects but did not have lower free $1,25(\mathrm{OH})_{2} \mathrm{D}$ levels. Although we did not determine whether these particular alcoholic subjects had evidence of vitamin D deficiency (e.g., osteomalacia), one of us (Bikle, D. D., H. K. Genant, C. Cann, R. R. Recker, B. P. Halloran, and G. J. Strewler, manuscript submitted for publication) has found no evidence of osteomalacia on transcortical biopsy of the iliac crest in another group of alcoholics. Conceivably, the available $1,25(\mathrm{OH})_{2} \mathrm{D}$ levels are adequate for normal target tissue response in these subjects with liver disease despite the reduced total $1,25(\mathrm{OH})_{2} \mathrm{D}$ levels. In contrast, the free $1,25(\mathrm{OH})_{2} \mathrm{D}$ levels in the pregnant subjects were elevated, although not to the degree to which total $1,25(\mathrm{OH})_{2} \mathrm{D}$ levels were increased. From a physiologic perspective, an elevated free $1,25(\mathrm{OH})_{2} \mathrm{D}$ level would help to provide the additional calcium required for the developing fetus and is consistent with the increased intestinal calcium absorption observed during pregnancy (15).

Although we expected a simple correlation between DBP levels and total $1,25(\mathrm{OH})_{2} \mathrm{D}$ and percent free $1,25(\mathrm{OH})_{2} \mathrm{D}$ levels, several discrepancies were apparent. In particular, in the normal and pregnant subjects, percent free $1,25(\mathrm{OH})_{2} \mathrm{D}$ was only modestly decreased by substantial increments in DBP. Substantial reductions in DBP below the normal levels in the subjects with liver disease were associated with much greater changes in the percent free $1,25(\mathrm{OH})_{2} \mathrm{D}$ levels. This discrepancy may be attributable to changes in serum albumin and lipoproteins, which also bind $1,25(\mathrm{OH})_{2} \mathrm{D}(3)$, or to the possibility that the affinity of DBP for $1,25(\mathrm{OH})_{2} \mathrm{D}$ varies from person to person, especially under different physiologic or pathophysiologic conditions. Future investigations using direct measurements of free $1,25(\mathrm{OH})_{2} \mathrm{D}$ should help to distinguish between these possibilities.

\section{Acknowledgments}

We thank Dr. James Murai and Dr. Pentti Siiteri for their help in developing the centrifugal ultrafiltration technique and for providing samples from pregnant subjects, Dr. Carl Mendel and Dr. Ralph Cavalieri for their help with equilibrium dialysis, Dr. Elizabeth Ryzen and Dr. Robert Rude for providing samples from alcoholic subjects, M. A. Kowalski for technical support, and Mary Jean Moore for editorial assistance.

This work was supported by National Institutes of Health grants (AM 28116 and AM 28292) and the Veterans Administration.

\section{References}

1. Haddad, J. G., Jr. 1979. Transport of vitamin D metabolites. Clin. Orthop. Relat. Res. 142:249-261.

2. Haddad, J. G., Jr., and J. Walgate. 1976. 25-hydroxyvitamin D transport in human plasma. Isolation and partial characterization of calcifediol-binding protein. J. Biol. Chem. 251:4803-4809.

3. Silver, J., and M. Fainaru. 1979. Transport of vitamin D sterols in human plasma: effect of excess vitamin D, 25 hydroxyvitamin D and 1,25 hydroxyvitamin D. Eur. J. Clin. Invest. 9:433-438.

4. Bouillon, R., F. A. Van Assche, H. Van Baelen, W. Heyns, and P. De Moor. 1981. Influence of the vitamin D-binding protein on the serum concentration of 1,25-dihydroxyvitamin $\mathrm{D}_{3}$. J. Clin. Invest. 67:589-596. 
5. Haddad, J. G., L. Hillman, and S. Rojanasathit. 1976. Human serum binding capacity and affinity for 25-hydroxyergocalciferol and 25-hydroxycholecalciferol. J. Clin. Endocrinol. Metab. 43:86-91.

6. Ellis, G., and K. Dixon. 1977. Sequential-saturation-type assay for serum 25-hydroxyvitamin D. Clin. Chem. 23:855-862.

7. Bouillon, R., P. Van Kerkhove, and P. De Moor. 1976. Characteristics of the vitamin D-binding protein in different species. Calcif. Tissue Res. 21(Suppl):172-176.

8. Seino, Y., M. Ishida, K. Yamaoka, T. Ishii, T. Hiejima, C. Ikehara, Y. Tanaka, S. Matsuda, T. Shimotsuji, H. Yabuuchi, S. Morimoto, and T. Onishi. 1982. Serum calcium regulating hormones in the perinatal period. Calcif. Tissue Int. 34:131-135.

9. Steichen, J. J., R. C. Tsang, T. L. Gratton, A. Hamstra, and H. F. DeLuca. 1980. Vitamin D homeostasis in the perinatal period: 1,25-dihydroxyvitamin $\mathrm{D}$ in maternal, cord, and neonatal blood. $N$. Engl. J. Med. 302:315-319.

10. Lund, B., and A. Selnes. 1979. Plasma 1,25-dihydroxyvitamin $\mathrm{D}$ levels in pregnancy and lactation. Acta Endocrinol. 92:330-335.

11. Kumar, R., W. R. Cohen, P. Silva, and F. H. Epstein. 1979. Elevated 1,25-dihydroxyvitamin D plasma levels in normal human pregnancy and lactation. J. Clin. Invest. 63:342-344.

12. Haddad, J. G., Jr., and J. Walgate. 1976. Radioimmunoassay of the binding protein for vitamin D and its metabolites in human serum. Concentrations in normal subjects and patients with disorders of mineral homeostasis. J. Clin. Invest. 58:1217-1222.

13. Brown, D. J., E. Spanos, and I. Macintyre. 1980. Role of pituitary hormones in regulating renal vitamin $\mathbf{D}$ metabolism in man. Br. Med. J. 280:277-278.

14. Reddy, G. S., A. W. Norman, D. M. Willis, D. Goltzman, H. Guyda, S. Solomon, D. R. Philips, J. E. Bishop, and E. Mayer. 1983. Regulation of vitamin D metabolism in normal human pregnancy. $J$. Clin. Endocrinol. Metab. 56:363-370.

15. Heany, R. O., and T. G. Skillman. 1971. Calcium metabolism in normal human pregnancy. J. Clin. Endocrinol. Metab. 33:661-670.

16. Bouillon, R., H. Van Baelen, and P. De Moor. 1977. The measurement of the vitamin D-binding protein in human serum. $J$. Clin. Endocrinol. Metab. 45:225-231.

17. Barragry, J. M., D. Corless, J. Auton, N. D. Carter, R. Long, J. D. Maxwell, and S. Switala. 1978. Plasma vitamin D-binding globulin in vitamin $\mathrm{D}$ deficiency, pregnancy, and chronic liver disease. Clin. Chim. Acta. 87:359-365.

18. Imawari, M., and D. S. Goodman. 1977. Immunological and immunoassay studies of the binding protein for vitamin D and its metabolites in human serum. J. Clin. Invest. 59:432-442.

19. Barragry, J. M., M. W. France, N. D. Carter, J. A. Auton, M. Beer, B. J. Boucher, and R. D. Cohen. 1977. Vitamin-D metabolism in nephrotic syndrome. Lancet. 2:629-632.

20. Schmidt-Gayk, H., W. Schmitt, C. Grawunder, E. Ritz, W.
Tschope, V. Pietsch, and K. Andrassy. 1977. 25-hydroxy-vitamin-D in nephrotic syndrome. Lancet. 2:105-108.

21. Goldstein, D. A., B. Haldimann, D. Sherman, A. W. Norman, and S. G. Massry. 1981. Vitamin D metabolites and calcium metabolism in patients with nephrotic syndrome and normal renal function. $J$. Clin. Endocrinol. Metab. 52:116-121.

22. Davies, M., E. B. Mawer, H. J. Klass, G. A. Lumb, J. L. Berry, and T. W. Warnes. 1983. Vitamin D deficiency, osteomalacia and primary biliary cirrhosis: response to orally administered vitamin $D_{3}$. Dig. Dis. Sci. 28:145-153.

23. Korkor, A., J. Schwartz, M. Bergfeld, S. Teitelbaum, L. Avioli, S. Klahr, and E. Slatopolsky. 1983. Absence of metabolic bone disease in adult patients with the nephrotic syndrome and normal renal function. J. Clin. Endocrinol. Metab. 56:496-500.

24. Kaplan, M. M., M. J. Goldberg, D. S. Matloff, R. M. Neer, and D. B. P. Goodman. 1981. Effect of 25-hydroxyvitamin $D_{3}$ on vitamin D metabolites in primary biliary cirrhosis. Gastroenterology. 81:681-685.

25. Long, R. G., E. Meinhard, R. K. Skinner, Z. Varghese, M. R. Wills, and S. Sherlock. 1978. Clinical, biochemical, and histological studies of osteomalacia, osteoporosis, and parathyroid function in chronic liver disease. Gut. 19:85-90.

26. Malluche, H. H., D. A. Goldstein, and S. G. Massry. 1979. Osteomalacia and hyperparathyroid bone disease in patients with nephrotic syndrome. J. Clin. Invest. 63:494-500.

27. Hammond, G. L., J. A. Nisker, L. A. Jones, and P. K. Siiteri. 1980. Estimation of the percentage of free steroid in undiluted serum by centrifugal ultrafiltration-dialysis. J. Biol. Chem. 255:5023-5026.

28. Snyder, S. M., R. R. Cavalieri, I. D. Goldfine, S. H. Ingbar, and E. C. Jorgensen. 1976. Binding of thyroid hormones and their analogues to thyroxine-binding globulin in human serum. J. Biol. Chem. 251:6489-6494.

29. Haddad, J. G., and K. J. Chyu. 1971. Competitive proteinbinding radioassay for 25-hydroxycholecalciferol. J. Clin. Endocrinol. Metab. 33:992-995.

30. Eisman, J. A., A. J. Hamstra, B. E. Kream, and H. F. DeLuca. 1976. A sensitive, precise, and convenient method for determination of 1,25-dihydroxyvitamin D in human plasma. Arch. Biochem. Biophys. 176:235-243.

31. Walsh, P. G., and J. G. Haddad. 1982. "Rocket" immunoelectrophoresis assay of vitamin D-binding protein (GC Globulin) in human serum. Clin. Chem. 28:1781-1783.

32. Bikle, D. D., E. W. Murphy, and H. Rasmussen. 1975. The ionic control of 1,25-dihydroxyvitamin $D_{3}$ synthesis in isolated chick renal mitochondria: the role of calcium as influenced by inorganic phosphate and hydrogen ion. J. Clin. Invest. 55:299-304.

33. Bikle, D. D. 1980 . Studies of the chick renal mitochondrial 25 hydroxyvitamin $\mathrm{D}_{3}$ 24-hydroxylase. Biochim. Biophys. Acta. 615:208222. 